\title{
The translingual subjects: Shaping identities and deconstructing rainbowism in One Foreigner's Ordeal
}

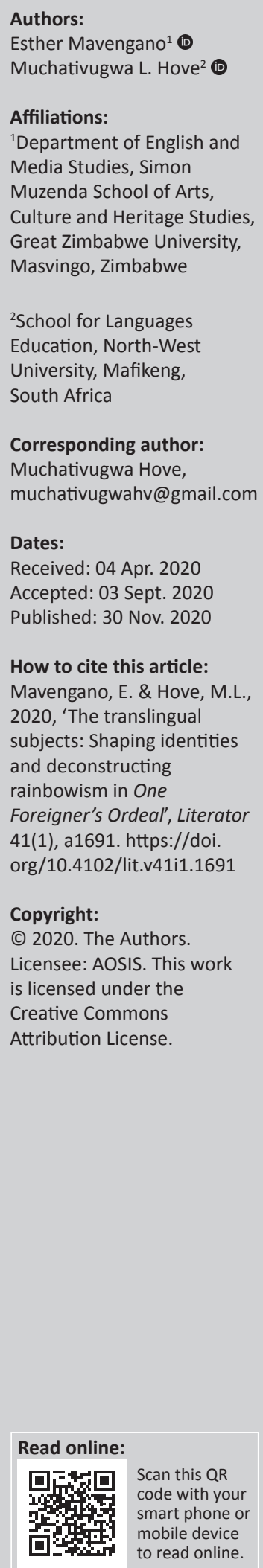

\begin{abstract}
The end of the apartheid era in South Africa inaugurated an increased mobility and accessibility to previously prohibited spaces. Although African migrant populations are still highly regulated in South Africa, their presence has also profoundly transformed the country's present-day sociolinguistic and cultural landscape. The textual construction of the literary text in this study draws attention to the post-structuralist perspective which argues that languages are not closed entities but rather open systems utilised for expressive purposes in specific social contexts. Most significantly, recent sociolinguistic studies show that languages are no longer regarded as discrete systems in communication because they form expansive linguistic repertoires in contact spaces. Such an understanding of multilingual use facilitates communication across cultural, linguistic and national borders, thereby subverting exclusionary normative practices. The present article draws from translingual perspectives to examine communicative practices in literary discourse. A close textual analysis is adopted to identify how translingual practices make languaging a contested terrain meant to project multi-voiced and multi-perspectival discourses with transformative capacities in the context of the 'rainbow nation' metanarrative.
\end{abstract}

Keywords: sociolinguistics; linguistic landscape; multi-voicedness; post-structuralism; rainbowism; translingual subjects.

\section{Introduction}

Recent research into contemporary sociolinguistic and cultural realities in South Africa has raised intriguing insights and questions about the notion 'rainbow nation'. Archbishop Desmond Tutu coined the term to describe a utopian vision of the democratic post-1994 South Africa in which the multi-ethnic and transcultural communities were expected to come together and forge a new interracial community that accommodated unity in diversity. However, the unfolding events in post-apartheid South Africa have led many scholars such as Tswane (2009), Patterson (2017) and Mojisola (2019) to question the clairvoyant and semantic gravitas of this term. Recently, many critics and scholars have criticised rainbowism as a short-sighted and fallacious political construct. They claim that in reality, South Africa does not belong to all those who live within its geographical borders. This compels a re-focusing of our attention to the pertinent challenges of multilingualism and diversity. In this article, we discuss linguistic constructs of the novel One Foreigner's Ordeal as countering binarism and segregation with the view that language use is an instrumental strategy for representation and identity construction in the post-apartheid era. This is because according to Fairclough (1991) and Foucault (1995), language mirrors the power relations in social contexts. Hall (1996) also views language as an essential instrument in identity construction, and hence notions of self and belonging are 'languaged'. Therefore, translanguaging and the discursive strategies adopted become significant sites to engage with the mechanisms of resistance, the politics of in/visibility and de/construction of the concept of the rainbow nation in narrative and polyvocal fictive discourses.

\section{Synopsis of the novel One Foreigner's Ordeal}

The novel One Foreigner's Ordeal, published in 2012, by a Zimbabwean writer, Tavuya Jinga, who lives in the diaspora, is largely set in South Africa; only Chapter 1 and a small part of Chapter 2 are set in Zimbabwe. The protagonist in One Foreigner's Ordeal is a Zimbabwean teacher who flees his homeland at the peak of that nation's economic and political crises. Before he departs, readers encounter a myriad of economic, political and social problems in Zimbabwe. Just like other citizens who fled Zimbabwe in 2008, the protagonist's contemptible condition is a push factor. Previously, the protagonist had no such intention, but he regards flight as a survival strategy that calls for neither planning nor reasoning. The novel foregrounds the harrowing experiences and 
threadbare lives of immigrants in South Africa; their ordeal is compounded by overwrought and exclusionary politics in the post-apartheid society. This novel is purposefully selected for its striking linguistic construction and rendition of diverse language codes. This represents an innovative departure from the monolingual practices that generally characterise fictional writing. The most fascinating aspect of this text is its attempt to defy any categories or territorial borders because migration and the notion of deterritorialisation are represented as messy and complex.

\section{The cross-cultural semiotic orientation: The artist's sensibility to the language question}

Yebo (2011) observes that the subject of language and languaging has been a long-standing controversy amongst critics and writers of African literature. The question of which language to use for literary expression in African literature can be traced to the 1962 Conference for African writers at Makerere University in Kampala, Uganda. The front runners in this debate are Chinua Achebe and Ngugi wa Thiong'o. On the one hand, Achebe (1965) strongly argues that European languages such as English and French can be creatively appropriated or Africanised for the expressive needs of the African people, and on the other hand, Ngugi (1994) views the use of imperialist languages as a betrayal of the African people and their efforts towards decolonisation. Ngugi (1994) submits that the cultural and spiritual subjugation of the African people which is encoded in imperialist linguistic codes curtails creativity and asserts that Africans can liberate themselves culturally and linguistically through writing in their mother tongues. The writers and scholars engaged in this polemic discussion have not reached consensus on how this language question can be resolved. The contemporary thought about languaging and politics of representation faces a major challenge vis-à-vis the sociolinguistic diversity of African countries (Kunene 1992; Ukam 2018). The African continent is characterised by multiethnicity and multilingualism. These multiple cultures and languages in Africa get more complicated in contemporary times because of increased ethnic cleansing, migration and mobility. The peculiarity of Jinga's linguistic style positions his novel, One Foreigner's Ordeal, in this robust language debate. We argue that Jinga's translingual aesthetics has come to define the complex realities of African politics and fiction today. The novel subverts linguistic determinism and offers a transcultural model through the polyglossia of the characters in contact within a new and reframed context that subsequently informs this translingual text.

\section{The translingual paradigm}

Canagarajah (2018) views translingualism as a shift from a structuralist paradigm that considers language as a self-defining and closed structure, set apart from its social context. He further explains that translingualism recognises languages as mobile, expansive and situated social practices. Translingualism acknowledges many versions in the languaging practices such as translanguaging, plurilingualism and metrolingualism (Canagarajah 2018). For Canagarajah (2007:98), translingualism draws attention to linguistics that treats human agency, context, diversity, multilingualism and multimodality as the new norm. It is integral to the understanding of verbal and semiotic resources in communication. Translingualism reconsiders verbal and semiotic resources as interacting synergistically to generate new grammars and meanings beyond the structuralist and functional meanings ascribed to verbal and semiotic structures. Thus, translinguals have the capacity of transgressing structuralist and semantic boundaries in communication to generate new possibilities for words and worlds. In other words, translingualism departs from making boundaries between languages because languages in contact and the immanent tensions are manifest in the productive text. Translingualism as an analytical concept therefore offers ever new ways to assess the literary uses of language.

\section{Rainbow nation and the conflicts of post-apartheid society}

The term 'rainbow nation' articulates the ideals of respect for human dignity, justice, enjoyment of freedoms, social cohesion, racial harmony, equality and unity in diversity (Tutu 2005). The aspirations of this imagined nation are informed by the recognition that South Africa is characterised by ethnic, linguistic and racial heterogeneity (Gqola 2001). Whilst these aspirations are visionary, the present study argues that it is problematic to ignore the palpable and throbbing tensions in contemporary South Africa. Gqola (2001) observes that there is an increase in scholarship that contests the term 'rainbow nation'. Milazzo (2013), commenting on post-apartheid fiction written by black writers, observes that the contemporary novels continue to direct attention to the multifarious and obscene legacies of apartheid. Such narratives invite us to witness the enduring differential values ascribed to black and non-black lives. The pathetic living conditions of the majority of black people in post-apartheid society have found attention in a number of novels such as Mhlongo's Dog Eat Dog and After Tears, Moele's Room 207 and Mpe's Welcome to Our Hillbrow.

Bock and Hunt (2015) add that although apartheid officially ended in 1994, race and ethnicity have remained primary markers of identity in South Africa. Paradoxically, discrimination, socio-economic inequalities and injustices persist, showing the stark ambivalence, and complexities of identity construction and belonging that writers grapple with in re-thinking and re-imagining the rainbow nation in a post-apartheid society awash with multiple challenges. This implies that despite the legal countenance of non-racialism in the Constitution of the Republic of South Africa, streaks of racism and schisms attributed to ultra-nationalism and ethnic enclaves have remained a startling reality of the rainbow nation. Perhaps, this could be regarded as a pessimistic thesis that overlooks transformative efforts and gains made so far in post-apartheid society. Yet, these remarks are significant especially if we consider the historical circumstances that led 
to the sheer economic inequalities in present day South Africa. The scepticism in such observations suggests that rainbowism has remained ambiguous, problematic and contested as masking the stasis in transformations that could inaugurate a sense of inclusion, belonging, justice and equality. Why is it that the utopian vision of a rainbow nation has been troubled and contested? There is a need to 'live the talk' and make the ineluctable rainbow nation a reality for the majority of the marginalised people in contemporary South Africa. The Title One Foreigner's Ordeal draws immediate attention to the polemical subject of discrimination that generally marginalises belonging and identity construction of the other. Addressing the tensions of inclusion and exclusion that are remnants of South Africa's apartheid history, as well as advancing the socio-economic justice envisaged in this society is bound to create a more cohesive and coherent narrative of social harmony.

The ambivalent conception of newness in post-apartheid society brings into question the motives behind a romanticised and sanitised dissemination and circulation of the term 'rainbow nation' and dramatises, amplifies and mocks simultaneously the illusions of equality, justice and racial harmony. By raising this question, writers and researchers need to rethink ways of creating a democratic space that promotes healthy human relations. This invites an urgent reassessment of the urgency for transformation. Patterson (2017) argues that South Africa is not healed from its wounded past; while freedom has come, the material gains remain elusive for the majority of black subjectivities.

This study interrogates and foregrounds the idea of languaging rainbowism through a close analysis of One Foreigner's Ordeal. In our analysis, we do not simplify nor gloss over the complexities related to the concept rainbowism. We discuss the complexities in situ to amplify critical attention to this volatile subject. Like Bakhtin (1981) who asserts that language in discourse is power-laden and tension-filled, Yuval-Davis (2011) observes that in South Africa, language is a contentious socio-political construct that marks the distinction between 'them' and 'us'. The term 'rainbow nation' contradicts its semantic signification in the context of xenophobia, inequalities and inter-ethnic conflicts that have been reported from 2008, 2012 and 2015 to date. Thus, scholars such as Hove (2017) and Vambe (2019) have spurned rainbowism as just another myth and a politicised fallacy that has lost its seriousness.

Msengana (2006) argues that race and ethnicity have remained principal axes of consciousness because South Africans generally think about themselves as an exclusive and exceptional enclave. Bhabha (1993) highlights the complicated and complex nature of historical memory when he explains that

... remembering is never a quiet act of introspection or retrospection. It is a painful re-membering, a putting together of the dismembered past to make sense of the trauma of the present. (p. 121)
Vambe (2019) also notes that there are 'bizarre remnants of apartheid' in imagining the present South Africa.

Gqola (2001) argues that major change is needed in terms of human relations because memories of the past continue to painfully stoke the present angst. Gqola's argument is still valid many years after the end of apartheid because the postapartheid nation has not been very successful in taking new inclusive trajectories and othered bodies like African foreigners are pathologised and excluded from the juridical mechanisms for citizenship. This is evident in the deeply rooted historical inequalities and asymmetric distribution of economic and reputational capital. According to Bakhtin (1981), language is the medium through which a hierarchical structure of power is perpetuated and contested. In South Africa today, this hierarchy as reflected in language use and languaging practices suggests the unresolved racial tensions, discriminatory practices and the current inter-ethnic rivalries that persist in post-apartheid society as projected in the Bale ka mo (insiders) or Matlwantle (outsiders) conundrum in the novel scrutinised in this article.

\section{Voice and perspective in translanguaging}

The terms 'voice' and 'perspective' can be defined in more than one way. Wales (2014) defines perspective as an orientation and position from which something is observed and considered. Language is a medium through which beliefs, perceptions and values are communicated. Bakhtin's (1981) concept of multivocality affords insights in reading translingual practices in fictional discourse. It refers to the presence of multiple perspectives and speaking positions on specific topics and subjects expressed through language. This notion of multivocality disrupts the idea of a single consciousness in discursive practices. Holquist (2002) explains that Bakhtin views linguistic utterances as contested terrain in which multiple meanings and world views are voiced linguistically. Canagarajah (2013) and Kachru (1992) argue that linguistic silos are meant for exclusion and surveillance of the perceived Other. The merging of various linguistic codes in novelistic discourse as demonstrated in One Foreigner's Ordeal is thus meant to mediate these social spaces and create voice for the marginalised groups that continue to negotiate audibility in contact situations (Canagarajah \& Matsumoto 2016). We also get versions of the perceived Matlwantle (outsiders) and Ba ka mo (insiders), the former feeling rejected and marginalised by the latter whose concerns for economic, moral and social well-being jettison the principles of the humanist philosophy encoded in Batho Pele (people first) (Jinga 2012:73). Jinga's text suggests alternative perceptions of nationhood and African identities through its representation of language use as a contested site, an arena for re-examination of socially constructed linguistic borders. The anger and frustration of black South Africans frequently erupt in the form of xenophobia, creating a new form of 'black-on-black' apartheid and othering of lekwerekwere (foreigners) as rightly observed by the narrator 
because in the post-apartheid era, South Africans have targeted and stigmatised African migrants. The narrator notes:

... Apartheid is very immoral and the South African struggle against apartheid was one of the most protracted. It has taken some people many years to accept that black and white people are of equal worth. It appears to me it will take more time for black-on-black apartheid to end. (Jinga 2012:44)

Even the title of the novel draws our attention to the experiences of the migrant who is the foreigner - Ke makwerekwere batho ba (These people are foreigners) (Jinga 2012). This projects the messiness of migration, the intricacies of identity construction, the burden of representation and the nuances of belonging in a milieu where commitment to social justice and redistribution is fraught with austerity.

Jinga deploys multi-vocal discourse that is expressed through cross-cultural and interracial snippets of language in the text. The translingual characters have access to multiple cultures and diverse languages that are integrated into a unique expressive semiotic code reflective of the present sociolinguistic realities in South Africa. In addition, racial conflict in post-apartheid South Africa is one seminal theme that is developed in the novel. The farm workers in this novel show their awareness of the historically oppressive power of Afrikaans and English. The intersections of these two linguistic codes with the South African indigenous languages allow the text to project the historiography of the previously colonised and segregated people, and they equally contest Eurocentric narratives and authorise the stories of the indigenous South Africans. Through translingual stylisations and oral narrative aesthetics in the novel, an essentialist perspective is projected and interrogated in the emerging postcolonial poetics. Black South Africans attempt to recover their communal experience, consciousness and voice, yet polylanguaging suggests that essentialist identities need to deconstruct and reformulate rainbowism, citizenship and nationalism in the emerging realities of the post-apartheid society. Although Afrikaans and English were the languages of apartheid administration, reading the postcolonial poetics from a translingual paradigm, the novel presents a thrilling possibility of the dynamism of languages, where translingual identities are more preferable, and hence the translingual stylisations make these passages salient. It should be noted that the diversity of perceptions and experiences is represented through the polyphony of the translingual subjects. This breaks away from linguistic binaries in ideologies that dichotomise language users into natives and non-natives. Clearly, languaging as a verb allows envoicing strategies and narrative dynamics that have an important bearing on the development of a novel aesthetics of African literature, engaged in the deconstruction of long-standing linguistic hegemony. We note that Jinga's languaging style and narrative strategies emerge from the contact with the intangible rainbow within a multilingual and multi-ethnic context in post-apartheid society.

\section{Code-meshing and lexical transfer in One Foreigner's Ordeal}

Canagarajah (2013) explains that a synergy of linguistic codes in interaction is a communicative norm in multilingual and multi-ethnic settings. Jinga's novel adopts heteroglossic speech stylisations where languages mesh in transformative ways, generating new meanings and new grammars of the characters' experiences. Lexical transfer and linguistic codemeshing convey the varied linguistic orientations and at the same time deconstruct and interrogate cultural-linguistic boundaries that would otherwise define the characters in monolithic ways as they interact. There are fascinating instances of code-mixing, code-switching and lexical transfer which produce a complex translingual quality in this novel. For instance, xenophobia is viewed as cannibalistic in character as it ate its very own children and violates the 'Batho pele, principles of batho pele' (Jinga 2012:95), Operation Buyela Ekhaya (Operation Return Home) becomes a trope that inscribes the enclave existence, invisibility and unbelonging of foreigners. The text thus exposes grey areas in the new South Africa and poses these polemic questions: Who are the Bantu people? Who are the South Africans? What was the mfecane or lifaqane difaqane? (Jinga 2012:109) This linguistic border crossing, encoded in the ChiShona and isiNdebele languages, conveys an ambivalence of presence that is greatly enhanced in the setting of the novel as it pushes and relocates the central character into the South African maelstrom.

The insertion of Afrikaans and its semantic value inscribes the farm as a white Afrikaner territory that maintains apartheid divisions and boundaries alienating the people of South Africa. This presentation conveys the fickleness of the term rainbowism through black people whose lives are illustrative of precarity and political betrayal. The rainbow nation narrative becomes part of the necropolitics and vulgarity of power as submitted by Mbembe (2009). This conveniently sanitised political rhetoric is subverted by the discriminatory behaviour that continues to prevail on the farm as a locale. There is little genuine commitment demonstrated towards social integration, and this explains the slow progress towards accommodating the other witnessed on the white Afrikaner farm. The conversations between the white farm owner and black farm workers re-enact the polarised master-slave discourse and untenably tense apartheid racial relations. Afrikaans and English are linked to their historical functions as expressions of domination, exploitation and coercive imperial narratives. Upon approaching the farm, the narrator is startled by the following signage:

PRIVAAT EIENDOM [Private property],

GEEN INGANG,

AIKONA NGENA [No Entry].

The narrator also observes that almost always accompanying the AIKONA NGENA sign is the insignia for danger - a drawing in red, depicting the human skull and two femur bones set to cross each other and therefore inscribing the prohibition sign (Jinga 2012:102). 
The idea of fenced and gated farms is evocative because it draws a remarkable parallel with historical separatist configurations of space. Crossing these boundary fences, which symbolically chart the racial divide, Cartesian binaries of human existence are still problematic in post-apartheid society. Furthermore, land is still in the hands of the minority white people; the names of farm owners suggest this reading. 'Louis and Eizaan Viljoen, Dewald and Zandre Steekamp, Stephan and Zandel Coetzee, PLM Boerdey, Van Rensburg Boerdery and so on' (Jinga 2012:102). The Afrikaner territory fundamentally symbolises a site of white, male and patriarchal division, racism and economic inequalities which threaten healthy human co-existence; hence, the insignia for danger articulates these historical legacies. It is relevant to read the dominant conversations in African languages on the farm as an act of defiance, an assertion of difference and a craving for equality. This is particularly true if we consider that Afrikaans and English remain quintessentially associated with white supremacy, the subjugation of black people and racial domination. The function of black people on the farm as labourers rather than owners of the means of production reinscribes an archive of discriminatory practices that marginalise black labour and maintain and perpetuate Afrikaner and English hegemony.

In addition, the ideological construction of the farm speak about racial or social apartness and binarism where the black workers' conditions of precarity at this farm confirm and validate their transience and marginalisation. The white family lives in comfort in the spacious farmhouse, whereas the black workers languish in poverty and dehumanising conditions in the compound and the rows of decrepit structures. On his arrival at the farm, the narrator registers his shock in the following extract:

[...] The buildings before me were so dilapidated that I had a hard time imagining what animals the farmer had in mind when he constructed them. The mere thought of them still makes my insides churn. To make matters worse, a heavy smell pervaded the place, something very close to what one would smell in the vicinity of a mortuary after five continuous days of long hours of load shedding. (Jinga 2012:107)

The term 'animals' in this passage underscores the sorry state of affairs and the dehumanisation suffered by black workers on this farm. The bestiality ascribed to these human beings further inflates the existing paradoxes elided in narratives about colour-blindness and reconciliation in South Africa. The narrative highlights and invites us to interrogate the false images of racial harmony that are projected as harbingers of a new rainbow nation marking the end of racism.

The farm setting signifies multiple realities and affords us various interpretations of what this unchanged reality means for the black community on the farm that does not use Afrikaans as medium of communication. This presentation suggests resistance to Calvinist Volk nationalism that is exclusionary and hegemonic. Perhaps, the use of lexical items from different languages in this community serves to challenge the Afrikaner's monotheist discourse about white supremacy and spatial divisions. An examination of the linguistic composition of the farm community shows that it is a zone of cultural and linguistic hybridity, although the white farm owner remains aloof to the post-apartheid transformations that demand rehumanisation of the previously othered bodies. In view of the above submission, the novel conveys the struggle for inclusion in a country where the vestiges of apartheid are visibly inscribed everywhere. Clearly, the novel foregrounds the new audibility of indigenous South African languages and Shona to mark the presence of black South African and Zimbabwean or African immigrants, suggesting integration and a new continental configuration. Yet, a closer look confirms that Afrikaans is defamiliarised and becomes the language of the 'other', thereby projecting the interlocking structure of carceral space, which produces and intensifies the biopolitical cut between those who must live and those who may die in this translingual narrative (Punch 2013; Ruzumova 2015). It is important to note that the white people in this novel have no meaningful interaction with the black farm workers except viewing them as cheap labour objects in the means of production.

The physical distance between the Afrikaner family and the black workers who are clearly living in squalid conditions symbolically amplifies the ambiguous nature of racial relations in contemporary South Africa. This physical distance also signifies the economic and social divide between white and black people, a replica of the apartheid centreperiphery architecture. Black people are located at the periphery and their subservient positions maintain and perpetuate an apartheid configuration. In fact, the farm community defines itself in ethnic, linguistic, national and racial terms in a profoundly static way. The white farmers' cold and offensive attitude towards black people is telling evidence of racism. The following dialogue between a white farm owner and a black male job seeker serves to illuminate this point:

'Good morning, Sir. How are you? I am looking for work,' I said, killing two birds with one stone. Let me see your hands, he said ... Those hands are not for work. They are for thieving! ...Well, I wouldn't be looking for work if I were a thief, I said coolly, trying to force a smile. Within, I was choking with anger. Thieving had not been on my list of prospective careers. (Jinga 2012:113)

This representation of the farm community and tension-filled human relations suggests that segregation still lives on. This organising logic of carceral farm space finds concrete form in both the simple technology of fences, walls and gates, and in more complex technologies such as surveillance cameras, alarm systems, monitoring devices, property law and the criminal legal system. Sadly, because of power imbalances at play, black workers are projected as powerless. Their inability to resist the post-apartheid reinscription of segregation emanates from their unchanged participation in the economy (Strauss \& Corbin 2008; Rafapa 2018). Most importantly, 
black people's presence as farm workers signifies that economic power remains in the hands of the white minority and a few black people who have dubiously gained access to the economic hold. The male black characters become the subject of ridicule and humiliation because of these power dynamics. This is evident in the following dialogue:

'How old are you?' asked the man (the white farmer)

'I am thirty-eight', I replied.

'Why is your hair greying?'

The choir (black workers) laughed hard at this.

'You, black people grey prematurely, don't you?' he said, leaning forward a little and opening his blue eyes wider at me. (Jinga 2012:114)

The male narrator takes insults from the Afrikaner who is the owner of the farm in a stunning demonstration of the emasculation reminiscent of the colonial times. Hove's (2014) comments on masculinities are handy here. He notes that Anglo-Boer masculinities brutalise black masculinities. Such behaviour perpetuates narratives of the perceived inferior 'other' who is vulnerable in the hands of 'super males'. When the black workers laugh at the irascible jest, they submit to both economic and material inferiority. Hove (2014) aptly explains that white masculinities seek to subdue, emasculate and smother black masculinities. In this respect, the laughter reflects what Fanon (1952/2008:93) regards as 'an internalized inferiority that naturalises submission to white authority'. Biko's (2004) work is also useful to our understanding of the psyche of these black farm workers when he observes that colonialism and apartheid left most black people in South Africa with an inferiority complex. These observations are apt here; therefore, crossing and navigating a complex racial terrain is also a cognitive process that requires transforming the mindsets of both the oppressors and the oppressed. Several post-apartheid contradictions are conveyed in the manner in which economic divisions and racial stereotypes persist in the novel.

\section{Seeking linguistic justice and national integration}

The appropriation and transliteration of English contradicts and often subverts monolithic versions of language (Pennycook 2008). The notion of native or non-native speaker is problematised through these translingual practices. According to Kachru's (1992) World Englishes paradigm, linguistic transgression facilitates the appropriation and use of English in local contexts. This means that language use is contextual and situational. The translingual paradigm recognises the power of language users and their unique contexts to shape language to specific meanings and interpretations (Milazzo 2017; Pennycook 2007). Translingual theory redefines and interrogates monoglossic notions of fluency, proficiency and language competence by departing from language conventions and welcoming dynamic processes of language use (Gopaldas 2016; Helgesson \& Kullberg 2018). Translinguals possess an amalgam of competencies that dynamically appropriates a number of linguistic codes. Kachru (1992) asserts that appropriation of a plurality of English(es) by speakers from the Outer Circle are necessary strategies of enacting linguistic justice. Chinua Achebe, the African literary giant, asserts in Morning Yet on Creation Day that:

... the English language will be able to carry the weight of my African experience. But it will be new English, still in full communication with its ancestral home, but altered to suit its new African surroundings. (Achebe 1975:78-84)

English, in Achebe and other writers, is reinvented by speakers from the Outer Circle who seek legitimating practices in order to express themselves and in the process assert their linguistic rights. Mr Zozo, a black South African, is one such speaker in the novel who does not pay attention to the grammaticality of English but rather uses it to assert a precarious identity and legitimacy of naming the wor(l)d in the communicative processes:

'Women not nice', he complained. 'Me tell him come last night please, this is your chance. She don't come. He say I am not feeling well. Now she start put call back. Why? His chance is go. It's chance of another. He must wait for her chance! (Jinga 2012:60)

The gendered pronouns 'he' and 'her' are perversely used in a translingual aesthetics in this character's English, serving to subvert Eurocentric constructs of linguistic identity and belonging to the apparatus called the nation. The emerging post-apartheid communities are implicitly encouraged to promote code-meshing and use varieties of Englishes in order to generate new meanings and new grammars commensurate with the lived realities of the post-apartheid state. Therefore, it can be argued that the appropriation of English by this character demonstrates that the language is no longer a sacrosanct property owned by its native speakers. Linguistic innovation here deconstructs hegemonic discourses previously held by its native speakers as well as the educated Africans. Such personal and subjective use of English serves as a decolonising imperative in the narrative that frees black post-apartheid agents from an imposed linguistic inferiority complex.

Mr Zozo claims that he knows isiZulu, isiXhosa, tshiVenda, sePedi, Setswana, Afrikaans and English. This demonstrates the self-assertiveness that Bamgbose (1998) endorses in submitting that failure to recognise varieties of Englishes used by non-natives is a colonial legacy where English was used to discriminate against the non-native 'other'. This is an apt assessment because the narrator, who is a former Zimbabwean teacher of English, thinks Mr Zozo's English is unintelligible because the grammar in each of his speech acts is viewed as grammatically incorrect. This judgemental attitude is informed by Chomsky's (1965) generative grammar and the notion of an ideal native speaker which disregards sociolinguistic contexts. For Oboko and Ifechelobi (2018), new forms of English emerge in post-colonial African societies to construct a distinct African flavour. The passage also interrupts and subverts the privileged stellar position of the English language and effectively asserts linguistic differences as a new normativity in contemporary 
South African society. Polyvocal discourse is therefore constructed through English by speakers from the Outer and Expanding Circle which is a contemporary thought in liberation linguistics in Kachru's (1992) World Englishes and Canagarajah's (2013) Translingual paradigm which resist structuralist traditions. Indeed, a language or its variety keeps accommodating new lexical items that are integrated to form new and distinct phrases, clauses and sentences reflecting the socio-political, economic and cultural situations of a society and such constructions generate new meanings that fulfil the communicative functions of such a linguistic environment. The narrator's disapproval of non-standard forms of English is ultimately regarded as a retrogressive evaluation of the contextual and linguistic essences in meaningful interaction. Language in this sense is a social construct and its usages should be fluid, dynamic and always in the process of becoming. Therefore, focus is on mutual intelligibility rather than accuracy and this claims legitimacy for other varieties of English in diverse speakers of this language.

\section{Translated songs: An imagined African human stage}

Translation is an important feature in translingual theory and the novel One Foreigner's Ordeal presents a number of translated songs. The songs are in Sesotho, chiShona and tshiVenda, showing a fundamental accommodation of the heteroglossia of an African community. In this way, translation and accommodation convey the artificiality and elasticity of cultural, linguistic and national boundaries. In one of the scenes, a powerful image of a gentleman dressed in a traditional Sesotho costume is deployed to render a stunning performance, gesturing and pleading with his ancestors for help in a multi-semiotic aesthetics:

Aaa badimo ba ka a na le a mpona na?

Letsoma kgomo, le mpoma ke le maratha bjalo

Letsoma kgomo, le mpona ke le malabulabu

Mpheng mosomo ke reke kgomo ... (Jinga 2012:24)

[My ancestors, do you see the sorry state I am in? Give me a job so that I can buy a cow ...]

This performed African identity fosters social cohesion and embraces the co-existence of the dead and the living in this libation because South African native and the immigrant are brought together through linguistic and sonic renditions in the songs. In other seSotho songs, the singer disregards cultural and national boundaries as he wishes to marry a Zimbabwean woman:

Mphelegetse Zimbabwe ke bone mosadi.

Mphelegetse Zimbabwe ke go nyala.

Basadi ba mo Mzansi ba a tshwenya ba nwa piri

Basadi ba mo Mzansi ba na le matepe ga ba hlomphe (Jinga 2012:15).

[Escort me to Zimbabwe, I saw a woman. Escort me to Zimbabwe I saw a woman to whom I want to get married. South African women are bothersome; they drink; South African women are annoying; they have no respect at all.]
Although this could be interpreted as sexist discourse, the transcultural, multilingual and thematic composition of the song hints at an inclusive human quest. Steiner (2010), talking about translation in the African novel, asserts that the layers of different languages within a text entail a remediation of cultures and world views which is also in keeping with rainbowism. These songs are appropriately utilised to valorise African spirituality and the human connections that existed in the pre-colonial era and counter the colonial ways of representing African ways of life. Wolff (2017) warns us against misrepresentation of Africa when he points out that the sociolinguistic realities of the continent are different from the west because most African countries are essentially pluralistic in terms of cultures, ethnic and linguistic composition. Thus, linguistic transfer traverses cultural boundaries and this stance appeals to the present black communities who want to return to African roots. The songs create a communal experience and stage a platform for cultural and national conversations which define a latent rainbowism that accommodates the vital and even vicarious experiences of the migrants. This idea is earlier presented in the novel when the narrator criticises the divisive effects of Berlin's cartography and distribution of African states, in his comments about the Limpopo River which is literally and figuratively used to examine the concept of borders:

This is the river whose majesty, way back in 1884, at the Berlin conference, the hawk-like eyes of the colonialists did not miss. It became a useful physical feature for their partition of Africa agenda. Communities which had interacted closely for centuries, which in some cases spoke the same language or sister language varieties, found themselves belonging to separate countries. Some suddenly became insiders and others outsiders. (Jinga 2012:10)

Later in the novel, after failing to secure an asylum permit from Home Affairs in Johannesburg, the narrator meets Rudzani, a South African man who generously offers him accommodation. Rudzani says to his friends:

This man is from Zimbabwe. He has been coming to Home Affairs to get an asylum permit but he has not been successful. I decided to take him home because I believe these people and we are born of the same father but we just have different mothers. (Jinga 2012:86)

Rudzani shows a deep sense of the cultural connectedness which jettisons and mocks the view that, Ke makwerekwere batho ba, which means that these people are foreigners (Jinga 2012:68). Rudzani strongly believes in an unbounded personhood that informs Ubuntu and therefore his kind gesture towards a fellow African sojourner. Significantly, Rudzani's nativised English effectively places him in an African cultural context that dynamically appropriates and domesticates the English language. His attitude impresses the narrator in immensely teleological ways:

I am not sure what Rudzani exactly meant by that. I am not quite sure if he knew that the Venda people who presently inhabit South Africa and Zimbabwe are descendants of the Shona who are mostly found in Zimbabwe today ... What I liked about the statement though was his acknowledgement that there was a common bond between us. (Jinga 2012:87) 
It is also worth noting that the merging of oral and written modes in a text written in English defies Eurocentric writing conventions and authorises the experiences of the indigenous African people. Thus, this fusion functions as textualisation of the slipperiness evident between oral and writing cultures. We interpret these songs as a historical aspect of sonic creativity and an expression of humanist thought that revives the collectivity and connectivity immanent in African traditional societies. In addition, the controversy surrounding Oliver Mtukudzi's national identity in this novel is pertinent in reading the destabilisation of a fixed national identity. Although Oliver Mtukudzi is a Zimbabwean musician, his music is immensely celebrated in South Africa, reflecting the essence of intercultural communication because the music is appreciated by people from diverse cultural and linguistic communities. The world of performative art is depicted as a transformative site and circuit that mediates borders and inscribes new conceptualisations of cultural, linguistic and national identity that privilege hybridity and new solidarities.

The inclusion of Shona in the novel dramatises the presence of Zimbabwean migrants in South Africa and demonstrates how the South African linguistic space has been semantically transformed by the experience of hosting trans-frontier nationalities. It is important to observe that Shona is used to perform a number of functions, thereby creating significant ambivalence in the (un)intended messages of this novel. Firstly, the inscription of the chiShona language does not convey a debilitating discourse of nostalgia or feelings of homesickness. Secondly, Shona is not used to inscribe a national identity or sentimental attachment with home, but rather utilised to comment and critique postcolonial Zimbabwean leadership. The protagonist ridicules and subverts the Zimbabwean state's hegemonic discourse by referring directly to a political jingle Rambai makashinga that encourages Zimbabweans to persevere in times of economic adversity. Mugabe is euphemistically referred to as 'Dad' in the novel, but he comes through as a despicable despot. In a different context, but related to the present discussion, Lee (2015) explains that a deliberate flouting of linguistic boundaries serves to reassert the presence of subaltern knowledges and voices. Similarly, the Zimbabweans in the diaspora use chiShona for audibility and visibility even though they are likely to be unheard from the physical distance between home and exile.

The two Shona songs from Oliver Mtukudzi that are cited in the novel disseminate potent political meanings. In both songs, the singer mourns his ruined home: Ndiyani wapunza musha wangu (Who is it that has demolished my home?). The rhetorical question indicts the destruction of the home that has subsequently caused immense discomfort in the home to the extent that the owner of the home is nonplussed. Ndatadza kushiringinya ndiri pamakumbo, Kushaya mufaro ndakatsamira rukuvhute rwavasekuru (Jinga 2012:91). Elsewhere, Hove (2019) argues that languaging can be a vehicle for problematising identity, belonging and becoming. It is relevant then that translingual subjects in this novel utilise language for such purposes. It is remarkable that the narrator remains an unnamed Zimbabwean teacher who later uses an invented identity, 'Sixty-Two', on the farm that initially becomes his entreport. Sixty-two is a number assigned to him when he got an 'orange picking' job on the farm. The other characters from Zimbabwe whose identities are obscured or changed are the 'animal driver' or 'old cattle minder' and 'VaMukarakate' who renamed himself Malome. The renaming inscribes new hybrid identity formations derived from spectral environments thereby disrupting and challenging the conventional ideas of permanent identities. The following conversation between the protagonist and the 'old cattle minder' gives credence to this interpretation:

Tinoda kuona VaMukarakate, I voluntureered in Shona (We wish to see Mr Mukarakate). In response, the 'cattle minder' says, 'Ho-o munoda kuona vaMalome? Ikozvino vari kumunda asi vanouya manje. Vanogara apo pari kubuda utsi apo!' (Oh, you want to see Malome? He must be at work in the orchards but he will be here any minute from now. He stays over there, from where that smoke is billowing! (Jinga 2012:104)

The unnamed old cattle minder is suspected to be a teacher from Zimbabwe who fled from the country's economic hardships. The man also switches to standard English when giving directions to new casualties of the economic implosion in Zimbabwe, supporting the valuation that he is possibly one of the Zimbabwean professional immigrants reduced to 'animal drivers and sekorobos drivers' (Jinga 2012:102). The narrator satirically says:

The old man was also driving. Of course, it has to be mentioned that driving rose to become the most preferred job among immigrants. Some drove mops across shop floors. Others drove toilet brooms very fast as if they had no fear of speeding fines from the marauding traffic cops. Many others drove sekorobos in private residences of South African citizens. (Jinga 2012:102)

The man's 'old age' elicits sympathy from Thobile who registers his protest in a mixture of seSotho and English, 'AOWA, AOWA, AOWA, TSHEBANNA! NO, NO, NO GENTLEMAN!' (Jinga 2012:105). Such pieta for the immigrants makes them reject any permanent and historical identities that link them to a nation that has made them vulnerable and marginalised, hence their desperate yearning to assume new names such as 'Sixty-Two', 'Malome' and 'Mafolo'. We interpret the newly acquired names as a desire to disconnect from the 'original' homeland, at the same time recognising that the copy cannot ever be an original, but a lamination. This implies that the new diasporic spaces provocatively unrobe and simultaneously empower migrants with expressive voice previously denied and muffled by Zimbabwean authorities. These characters shed their Zimbabwean identities and proffer their preferred Sesotho identity. This is a commendable transfigurative technique that provides insights into the configuration of the homeland within the macabre experiences of the migrants. There is a need to reassess our views about language and identity as well as language and the spectre of belonging. Both cultural and national identities that could be related to the use of the 
Shona language are resisted by these immigrant characters. Significantly, these characters serve to illustrate the construction of mutable, mobile and transformable identities. This reading concurs with Hall (1996) who asserts that identity is never complete but is defined, inscribed and accessible in language. Translanguaging in these passages becomes a flexible site of identity construction and selfexpression by the displaced people who speak back to the political authorities.

\section{The forging of a rainbow nation}

From the foregoing discussion, it is clear that the concept of a rainbow nation is interrogated and problematised in the novel One Foreigner's Ordeal through a focus on stories of the marginalised people. The novel resists exclusions grounded in monolithic discourses through its linguistic construction that promotes diversity and multiculturalism. Most importantly, the novel proffers suggestions for an alternative conceptualisation of the rainbow nation. In the novel, a pastor visits the farm community in South Africa and registers his disapproval of xenophobic attacks and negative perceptions and has this to say in isiNdebele:

Bangani bami, angazi ukuthi kwenzakalani lapa emhlabeni... amalanga lamabi. Liyazi ngensuku zokubandlulula abamhlope labensundu, isizalwane zakuleli zazibaleka zilubekise kumagumbi wonke, ziqonda kwamanye amazwe, zisiyaphephela. Kodwa yibo asebephendukela belwisa abantu ababebagcinile ngezinsuku bedubeka ... amalanga lamabi.

\section{This translated into English:}

My friends, I do not know what the world is coming to ... these are evil days. You know, during apartheid, the citizens of this country were fleeing in all directions to other countries to seek refuge. Today we are experiencing an about turn and people are attacking those who sheltered them when they were in their hour of need ... these are evil days. (Jinga 2012:140)

This extract theatricalises a central thematic concern about the politics of home and migration, belonging and identity in South Africa. The sermon highlights one of the ugliest aspects of contemporary South Africa where xenophobia, which is targeted at black African immigrants, apparently characterises a society that is far from attaining social cohesion. The pastor cites historical circumstances to remind the congregants of a shared past of pain and exodus. What is particularly perplexing is that xenophobic attitudes reflect how easily South Africans have forgotten the assistance they received in their hour of need from their neighbours. This deliberate forgetfulness, an offshoot of selective amnesia, serves to legitimise and maintain essentialist and exclusionary conceptualisations of belonging, citizenship and nationhood. The discriminatory experiences and conflicted narratives of xenophobia hint at post-apartheid anxieties about belonging. Such paradoxes make it very difficult for immigrants to identity with the rainbow nation. Immigrant populations are violently excluded and these are pertinent spheres that demand critical assessment at both the social and political levels. The pastor character uses a religious platform to debate and reflect on contemporary versions of an incendiary and dehumanising politics of exclusion (Hove 2017). Thus, history becomes an attribute of narrative that engenders a new awareness and inaugurates a new critical consciousness (Biko 2013; Gilroy 1993).

Hove (2017) interrogates xenophobia in the South African context of migration and increased mobility and argues that ideas of nation and nationality are increasingly complicated. $\mathrm{He}$ also points out that South Africa seems to nurture the idealised and romanticised notion of a rainbow nation that ignores the huge task concomitant in making this a reality. These post-apartheid ironies and paradoxes are also exposed in Operation Buyela Ekhaya (Operation Return Home) and Operation Fiela (an uncanny duplication of Operation Murambatsvina in Zimbabwe) that targets sweeping out 'makwerekwere' from South Africa. South Africans used pangas, assegais, sjamboks, fire, fists and booted feet to eject the foreigners (Jinga 2012:108). The novel, through codemixing and code-meshing where, for example, English and isiZulu are interchanged and blended to form a unique discursive encounter, illuminates the vagaries of space and belonging in this post-apartheid society. The following passages are compelling evidence of the ambiguities enshrined in narratives of the rainbow construct today. 'The sons and daughters of the soil involved in this noble operation should have taken a leaf from their Northern neighbour's Operation Murambatsvina (Operation Remove Dirt) launched in 2005' (Jinga 2012:108). This reference to the macabre Zimbabwean internal displacement of the urban poor people is highly significant because it establishes the parallel experiences engendered by these two operations that were characterised by violence and inhuman treatment of the displaced people. However, the narrator goes on to state that:

In the Mzansi case, the combatants slightly got mixed up on who exactly deserved to be knifed, punched, kicked, thrown out of a moving train or burnt. How was a dedicated cadre of this struggle supposed to differentiate a Ndebele from Mpumalanga's Kwa Ndebele in South Africa and one from Zimbabwe's Mzilikazi Suburb, Nkayi, Khezi or Mapisa? ... Let us suppose Lerato Mokoena, a South African, is married to Muzvondiwa Pazvakarambwa of Zimbabwe. Does that qualify Lerato for kwerekwere-ship as well? Who are we as Africans, as black people, as human beings? (Jinga 2012:109)

In the light of the above extracts, it is apparent that translingual strategies in Jinga's novel are not just idiosyncratic stylisations but rather serve as effective rhetorical resources that reveal the interconnection of cultures, languages and peoples in the social and political realm of the two nations. The definitions of perceived 'locals or us' and 'foreigners or others' are problematised and scrutinised. The novel projects a humanity that extends beyond these two countries, suggesting a complex rainbow nation that accommodates all. The present rainbow nation has some serious fissures which are ironically captured in the tag line on posters at the Home Affairs Crown Mines that reads 'There is hope at the end of the rainbow nation' 
(Jinga 2012:84). The semantic implications of this line remind us of a deferred long walk to rainbowism, an idea that is immediately rejected by the narrator who changes the line to 'There is hope in the rainbow' or 'There is hope within the rainbow' (Jinga 2012:84), thereby generating the tensions in reading and meaning-making. The elusive rainbow nation is an urgent human need in South Africa. These remarks register anxieties, bewilderment, cynicism and discontent with the present conditions in South Africa. The scribal change of this line becomes a subversive act that complicates the aspirations embedded in the symbolism of the rainbow. It also conveys the citizens' growing impatience with the long journey strewn with varying degrees of injustice and inequality. The post-apartheid society's discourses of integration have failed to bear satisfactory results. This is partly because navigation and transgression of boundaries is contaminated by frail policies and frayed ultra-nationalist politics that do not fully support the development of hospitality in a rainbow nation that embraces multilanguaging and multi-ethnicity in postapartheid society.

\section{Concluding remarks}

From this reading, the novel represents a linguistic space that is transformed by the contemporary socio-political environment in South Africa. The presence of African migrants has fundamentally reshaped the country's sociolinguistic landscape; hence, the deployment of a polyglossic code is an appropriate literary strategy to negotiate and contribute towards a novel linguistic rainbowism. The novel charts the limits of borders and foregrounds a new consciousness that embraces diversity and multiplicity. Thus, the translingual quality of the text affirms the aspirations of an egalitarian society replete with conversations about rainbowism. The novel also celebrates linguistic heterogeneity and further highlights that everyday communicative habits should foster a hybrid linguistic assemblage that redefines the present South Africa. In other words, Jinga's fictional narrative debunks and challenges racial and ethnic myths through its narrative linguistic strategies. Making the elusive rainbow nation a living reality is a complex task in the face of the evidence of double standards, racism, xenophobia, ambivalence from the authorities and hypocrisy amongst various sections of the post-apartheid society. These observations render the aporia of a rainbow nation a mere sanitised notion devoid of the practicalities of a new cartography. The country has remained deeply divided and unequal. It is indisputable that imagined transformation as encoded in the term 'rainbow nation' is a vexed and troubled agenda because such a notion is misunderstood, resisted and (re)constructed in myriad ways that are still to coalesce around an agenda of renewal and enterprise.

\section{Acknowledgements Competing interests}

The authors have declared that no competing interests exist.

\section{Authors' contributions}

All authors contributed equally to this work.

\section{Ethical consideration}

This article followed all ethical standards for research without direct contact with human or animal subjects.

\section{Funding information}

This research is partly funded by the NWU Postgraduate Bursary, the National Research Fund and was conducted under the auspices of the Indigenous Languages and Media in Africa (ILMA) Research Entity.

\section{Data availability statement}

The authors confirm that the data supporting the findings of this study are available within the article.

\section{Disclaimer}

The views and opinions expressed in this article are those of the authors and do not necessarily reflect the official policy or position of any affiliated agency of the authors.

\section{References}

Achebe, C., 1965, 'The African writer and the English language', Transition 4(18), 27-30. https://doi.org/10.2307/2934835

Achebe, C., 1975, Morning yet on creation day, Heinemann Educational Books, London.

Bakhtin, M.M., 1981, The dialogic imagination: Four essays, ed. \& transl. C. Emerson, Manchester University Press, Manchester.

Bamgbose, A., 1998, 'Torn between the norms: Innovations in world Englishes', World Englishes 17(1), 1-14. https://doi.org/10.1111/1467-971X.00078

Bhabha, H., 1993, The location of culture, Routledge, New York, NY

Biko, H., 2013, The great African society: A plan for a nation gone astray, Jonathan Ball Publishers, Cape Town.

Biko, S., 2004, I write what I like: Selected writings, Picador Africa, Johannesburg.

Bock, Z. \& Hunt, S., 2015, “II's just taking our souls back”: Discourses of apartheid and race', Southern African Linguistics and Applied Language Studies 33(2), 141-158. https://doi.org/10.2989/16073614.2015.1056196

Canagarajah, S., 2007, 'Lingua Franca English, multilingual communities and language acquisition', The Modern Language Journal 91(S1), 934-938. https://doi org/10.1111/j.0026-7902.2007.00678.x

Canagarajah, S., 2013, Translingual practice: Global Englishes and cosmopolitan relations, Routledge, New York, NY.

Canagarajah, S., 2018, 'Translingual practice as spatial repertoires: Expanding the paradigm beyond structuralist orientations', Applied Linguistics 39(1), 31-54. https://doi.org/10.1093/applin/amx041

Canagarajah, S. \& Matsumoto, Y., 2016, 'Negotiating voice in translingual literacies: From regimes to contact zones', Journal of Multilingual and Multicultural Development 38(5), 390-406. https://doi.org/10.1080/0143463 2.2016.1186677

Chomsky, N., 1965, Aspects of the theory of syntax, The MIT Press, Cambridge, MA. https://doi.org/10.21236/AD0616323

Fairclough, N., 1991, 'Language and ideology', Trabalhos em Linguistica Aplicada $17(1), 113-131$.

Fanon, F., 1952/2008, Black skin white masks, transl. C. L. Markmann, Plato Press, London.

Foucault, M., 1995, Discipline and punishment, 2nd edn., Vintage Books, New York, NY.

Gilroy, P., 1993, The black atlantic: Modernity and double consciousness, Harvard University Press, Cambridge, MA.

Gopaldas, A., 2016, 'A front-to back guide to writing a qualitative research article', Qualitative Market Research: An International Journal 19(1), 115-121. https:// doi.org/10.1108/QMR-08-2015-0074

Gqola, P., 2001, 'Defining people: Analysing power, language and representation in metaphors of the New South Africa', Transformation 47(1), 94-113. 
Hall, S., 1996, 'When was the postcolonial? Thinking at the limit' in I Chambers \& L. Curti (eds.), The Postcolonial Question, Routeledge, London.

Holquist, M., 2002, Dialogism: Bakhtin and his world, Psychology Press, London.

Helgesson, S. \& Kullberg, C., 2018, 'Translingual events: World literature and the making of language', Journal of World Literature 3(2), 136-152. https://doi. org $/ 10.1163 / 24056480-00302002$

Hove, M.L., 2014, 'Treacherous masculinities and assertive femininities: An interrogation of Sindiwe Magona's beauty's gift', Mediterranean Journal of Social Science 5(8), 533-548.

Hove, M.L., 2017, 'When tears become a language: Frictions in a xenophobic national "imaginary"', Journal of Transient Migration 1(1), 117-135. https://doi. org/10.1386/tjtm.1.1.117_1

Hove, M.L., 2019, 'Africa in Brathwaite: The matrix of cultural quest, identity and history as poetic vision', Literator 40(1), 1493. https://doi.org/10.4102/lit.v40i1.1493

Jinga, T., 2012, One Foreigner's Ordeal, Author House, London.

Kachru, B.B., 1992, 'Models for non-native Englishes', in B. B. Kachru (ed.), The other tongue: Englishes across cultures, 2nd edn., pp. 48-75, University of Illinois Press, Urbana.

Kunene, M., 1992, 'Problems in African-language literature: Tragedy and hope', Research in African Literatures 23(1), 7-15.

Lee, T., 2015, 'Translanguaging and visuality: Translingual practices in literary art', Applied Linguistics Review 6(4), 441-465. https://doi.org/10.1515/ applirev-2016-1003

Mbembe, A., 2009, 'On the postcolony: Interview, Chimurenga', viewed n.d., from https://www.chimurenga.co.za

Mojisola, A., 2019, 'I stand corrected, in Mojisola', Adebayo, Plays Two, Oberon Books, London. https://www.rajhashakiry.co.uk/projects/i-stand-corrected

Mhlongo, N., 2004, Dog eat dog, Kwela Books, Cape Town.

Mhlongo, N., 2007, After tears, Kwela Books, Cape Town.

Milazzo, M., 2013, 'Racial power and colourblindness: The black stories of Kgebetl Moele's room 207 and twenty-first black South African fiction', Journal of Commonwealth \& Postcolonial Studies 1(1), 33-59.

Milazzo, M., 2017, 'On white ignorance, white shame and other pitfalls in critica philosophy of Race', Journal of Applied Philosophy 34(4), 557-572. https://doi. org/10.1111/japp.12230

Moele, K., 2006, Room 207, Kwela Books, Cape Town.

Mpe, P., 2001, Welcome to our Hillbrow, University of Natal Press, Pietermaritzburg.

Msengana, N.W., 2006, 'The significance of the concept "Ubuntu" for educational management and leadership during democratic transformation in South Africa', $\mathrm{PhD}$ thesis, University of Stellenbosch, Cape Town.
Oboko, U. \& Ifechelobi, C., 2018, 'Domestication of English in Achebe's novels: A sociolinguistic overview', Journal of Languages, Linguistics and Literary Studies 6(2), 108-114.

Patterson, R.R., 2017, "From "Apartheid" to the "Rainbow Nation" and beyond: The representation of childhood and youth in South African coming-of-age narratives', Master's thesis, University of Stellenbosch, Cape Town.

Pennycook, A., 2007, Global Englishes and transcultural flows, Routledge, London.

Pennycook, A., 2008, 'English as a language always in translation', European Journal of English Studies 12(1), 33-47. https://doi.org/10.1080/13825570801900521

Punch, R.K., 2013, Introduction to social research: Quantitative and qualitative approaches, Sage, New Delhi.

Rafapa, J.L., 2018, Ruptures in harmonizing discourses: Exemplifications in some works of black and white writers in a democratic South Africa, Atiner's Conference pape series, No. 2439, Athens Institute for Education and Research, Athens, viewed n.d., from https://www.atiner.gr/papers/LIT2017-2439.pdf

Ruzumova, L., 2015, 'New homes for translingual: Re-examining cultural and linguistic belonging in contemporary Literature', L2 Journal 7, 134-140. https://doi. org/10.5070/L27122768

Steiner, T., 2010, 'Of cracked lenses: Cultural translation, opacity and the African novel', Social Dynamics 36(2), 302-314. https://doi.org/10.1080/02533952.2010.489332

Strauss, A. \& Corbin, J., 2008, Basics of qualitative research: Techniques and procedures for developing a grounded theory, 3rd edn., Thousand Oaks, London.

Tshawane, N.J., 2009, 'The rainbow nation: A critical analysis of the notions of community in the thinking of Desmond Tutu', PhD Thesis, Dept. of Philosophy, Practical \& Systematic Theology, University of South Africa.

Tutu, D,M., 2005, The rainbow people of God: A spiritual journey from apartheid to freedom, Doubleday, Cape Town.

Ukam, I.E., 2018, 'The choice of language for African creative writers', English Linguistics Research 2(2), 46-53. https://doi.org/10.5430/elr.v7n2p46

Vambe, T.M., 2019, Stories of milk, honey and bile: Representing diasporic African foreigner's identities in South African fiction, Intechopen. https://doi.org/10.5772/ intechopen.87245

Wa Thiong'o, N., 1994, Decolonising the mind: The politics of language in African literature, Heinemann, London.

Wales, K., 2014, A dictionary of stylistics, Longman, London.

Wolff, H.E., 2017, 'Language ideologies and the politics of language in post-colonial Africa', Stellenbosch Papers in Linguistics Plus 51, 1-22. https://doi.org/10.5842/51-0-701

Yebo, E., 2011, 'Nativisation of English in African literary texts: A lexico-semantic study of translation in Gabriel Okara's The Voice', International Journal of Humanities and Social Sciences 1(13), 202-208. https://doi.org/10.5539/ijel.v1n2p213

Yuval-Davis, N., 2011, 'Belonging and the politics of belonging', in J. McLaughlin, P. Phillimore \& D. Richardson (eds.) Contesting recognition: Identity studies in the social sciences, pp. 20-35, Palgrave Macmillan, London. 